\title{
Evaluation of clinical and haematological parameters in differentiation of feline immunodeficiency and feline leukemia virus infection
}

\author{
Nevenka Rudan ${ }^{1}$, Evica Marković ${ }^{2}$, and Nada Kučer ${ }^{3 *}$ \\ ${ }^{l}$ Department of Microbiology and Infectious Diseases with Clinic, Faculty of Veterinary Medicine, University \\ of Zagreb, Zagreb, Croatia \\ ${ }^{2}$ Veterinary and Food Safety Directorate, Ministry of Agriculture, Zagreb, Croatia \\ ${ }^{3}$ Clinic for Internal Diseases, Faculty of Veterinary Medicine, University of Zagreb, Zagreb, Croatia
}

\section{RUDAN, N., E. MARKOVIĆ, N. KUČER: Evaluation of clinical and haematological parameters in differentiation of feline immunodeficiency and feline leukemia virus infection. Vet. arhiv 87, 731-743, 2017.}

ABSTRACT

For this retrospective study clinical, haematological and virology parameters were analysed from 21 cats received at the Clinic for Internal Diseases of the Faculty of Veterinary Medicine, University of Zagreb, with severe clinical signs of feline leukaemia, feline immunodeficiency, or both diseases. The cats were of different breeds, different ages and forms of care. The history of the disease, temperature and breathing frequency were recorded for each cat. The presence of specific antibodies for feline immunodeficiency virus (FIV) was detected in serum samples from 10 cats, four females and six males. The presence of feline leukemia virus (FeLV) antigen was detected in 8 serum samples, from two females and six males. Three cats were FIV and FeLV positive, all of them male cats. Male cats and those with outdoor access are more often susceptible to infections. FeLV+ and $\mathrm{FF}+(\mathrm{FeLV}$ and FIV) cats are generally younger, than FIV + cats (seven of eight FeLV + cats are between 1 and 5 yrs old). Differences were noticed between FeLV and FIV positive animals in terms of haematological and biochemical values. Increased values for leukocytes, segmented and non-segmented neutrophils in cats positive for FeLV, FIV or both viruses were mainly determined, as well as a decreased number of thrombocytes, erythrocytes, Hb, HMT and MCV values in the majority of animals studied. In FeLV+ animals alterations in the number of lymphocytes (lymphocytosis and lymphopenia) were more prominent compared to FIV+ animals, in which leucocytosis was more prominent. No relationship between the severity of clinical symptoms and the age and sex of the animals was found.

Key words: FIV, FeLV, cats, naturaly infected, clinical signs, haematological signs

\footnotetext{
${ }^{*}$ Corresponding author:

Prof. dr. sc. Nada Kučer, Clinic for Internal Diseases, Faculty of Veterinary Medicine, University of Zagreb, Heinzelova 55, 10000 Zagreb, Croatia, Phone: +385 12390 344; E-mail: nkucer@vef.hr
} 
N. Rudan et al.: Clinical and haematological parameters of feline immunodeficiency and feline leukemia virus infection

\section{Introduction}

Domestic cats are susceptible to multiple retroviral infections, and two of these infections, FeLV and FIV, are connected with progressive immunodeficiency diseases (FONTENOT et al., 1992). FeLV is a gammaretrovirus responsible for fatal diseases in cats. It was discovered in 1964 in the UK (HARDY and ESSEX, 1986). FeLV infection has a major impact on cat life expectancy (MELI et al., 2010). The FeLV genome is comprised of only three genes necessary for replication and particle formation (gag, pol and env) which code for nine different viral proteins. For this reason it is only able to replicate in actively dividing cells, such as those in the bone marrow or the lining of the small intestine (SCHLECHT-LOUF et al., 2014). Long terminal repeat sequences within the genome serve a regulatory function, and contain enhancer sequences that are believed to be associated with the oncogenic nature of the virus (HOFMANN-LEHMANN et al., 2001). It is estimated that it infects up to $50 \%$ of free range cats (ADDIE et al., 2000; BOENZLI et al., 2014).

FIV is a lentivirus, genetically related to the human immunodeficiency virus (HIV) (BENDINELLI et al., 1995). FIV causes immunodeficiency disease in domestic cats, including a decrease in $\mathrm{CD} 4+\mathrm{T}$ cells and $\mathrm{CD} 8+\mathrm{T}$ cells, and increased susceptibility to opportune infections, and finally death (COLLADO et al., 2012; HARDY and ESSEX, 1986). Incidence of FIV infections in Europe significantly differs between the low percentage in Western European countries, to a high percentage in Italy, France, England and Northern European countries (COURCHAMP and PONTIER, 1994).

In the USA, FIV infects up to $14 \%$ of high-risk-group cats (YAMAMOTO et al., 1989). The frequency of FIV and FeLV coinfection is $16 \%$ in FeLV-infected cats in the United States (LEVY et al., 2006).

Both infections produce similar clinical signs, and it is difficult to establish a precise clinical diagnosis, especially if the animals are infected by both viruses (double infected), as they both may induce a state of immunosuppression which weakens the immunological defences. The prevalence of both gammaretrovirus and lentivirus infections in cats creates a need for sensitive and specific diagnostic assays to differentiate between these viral infections, to accurately diagnose the infectious agent, and to elucidate possible cofactors of immune deficiency syndromes (ENGLISH et al., 1994; ARJONA et al., 2007). Risk factors for infection are: male sex, mixed breed, outdoor access, increasing age, intact status, and existing health problems (COLLADO et al., 2012; DUNHAM and GRAHAM, 2008; GLEICH et al., 2009).

Reports show that both viruses infect other species of the Felidae family. The impact by humans on the environment is one of the main reasons for the spread of the disease in wild animals, enabling contact and transmission of the pathogen between domestic and wild animals (GOLDKAMP et al., 2008; MELI et al., 2010). 
N. Rudan et al.: Clinical and haematological parameters of feline immunodeficiency and feline leukemia virus infection

\section{Materials and methods}

Studied animals. For the purpose of obtaining clinical, serological, and biochemical test results for the presence of FeLV, FIV or both viruses, cats that were treated at the Clinic for Internal Diseases of the Faculty of Veterinary Medicine in Zagreb, were systematically checked, and of these 21 cats with developed clinical signs of feline leukaemia, feline immunodeficiency or both diseases were chosen for the study.

The cats were of different breeds, ages and forms of care. Four cats were kept inside a house at the time, but two of these were previously housed in animal shelters and one lived on the street. Eleven had free outdoor access, and 6 were backyard cats. Two cats were vaccinated against some infectious diseases.

Sampling. From each cat, blood was taken in test tubes and left for 30 minutes at room temperature to coagulate. Serum was separated by centrifugation at 2,500 revs for five minutes. After centrifugation, a sample was taken with a pipettor in a sterile Eppendorf test tube, and kept at a temperature of $2{ }^{\circ} \mathrm{C}$ to $7{ }^{\circ} \mathrm{C}$ until the test were performed.

Serological tests. For serological identification of specific antibodies for feline immunodeficiency virus and feline leukaemia virus, the SNAP Combo FeLV Ag/FIV test was used. It is a quick immunoensyme test for simultaneous discovery of feline leukemia virus (FeLV) and antibodies for feline immunodeficiency virus (FIV) in the serum, plasma or full blood of cats. The test for FeLV infection is based on diagnosing the FeLV p27 antigen, and the presence of specific antibodies for FIV, which proves that the cat was exposed to the FIV infection. The FIV antigen used in the conjugate is chemically inactivated.

Performance of ELISA for the detection of FIV / FeLV. Each package of the SNAP Combo FeLV Ag / FIV test consists of a SNAP device and one vial of $3.5 \mathrm{~mL}$ or 7 $\mathrm{mL}$ anti-FeLV / FIV Ag, HRPO conjugate, a reagent box, and a pipette for transfer to sample tubes. Each SNAP device contains $0.4 \mathrm{~mL}$ of washing solution and $0.6 \mathrm{~mL}$ of the substrate. The test and the reagents were stored at $2{ }^{\circ} \mathrm{C}$ to $7{ }^{\circ} \mathrm{C}$ (or $-20^{\circ} \mathrm{C}$ ). Antigen FeLV p27 binds on fixed antibodies, if present in the test sera. If specific antibodies for FIV are present in the test sera, they bind to the chemically inactivated FIV antigen. The operation was performed according to the manufacturer's instructions.

Haematological and biochemical tests. All the animals except one were submitted to haematology tests (ERC Lkc, Hb, HMT, MCV, MCH, MCHC, segmented and nonsegmented neutrophils, lymphocytes, eosinophils, monocytes, platelet) and biochemical parameters (glucose, bilirubin, urea, creatinine, protein, albumin, cholesterol, triglycerides, AST, ALT, AP, GGT, Ca, P).

Hematological tests were performed using a Serono Baker System 9120 CP blood counter and biochemical tests using a Technicon RA 1000 device. 
N. Rudan et al.: Clinical and haematological parameters of feline immunodeficiency and feline leukemia virus infection

\section{Results}

The results obtained by testing cat serums for antibodies to FIV and /or FeLV antigen are presented in Table 1.

Table 1. List of cats with severe clinical symptoms and a positive reaction to the presence of antibodies to FIV and /or FeLV antigen

\begin{tabular}{|c|l|c|c|l|l|}
\hline No & Breed & Sex & Age (yrs.) & Keeping & Positive on \\
\hline 1. & Domestic & male & 4 & outdoor access & FIV+FeLV+ \\
\hline 2. & Domestic & male & 3 & outdoor access & FeLV \\
\hline 3. & Domestic & male & 2 & adopted & FeLV \\
\hline 4. & Domestic & male & 3 & outdoor access & FIV+FeLV+ \\
\hline 5. & Cross breed & male & 9 & outdoor access & FIV \\
\hline 6. & Domestic & male & 3 & indoor & FIV+FeLV+ \\
\hline 7. & Domestic & male & 5 & indoor and backyard & FIV \\
\hline 8. & European & female & 0.6 & adopted & FIV \\
\hline 9. & Domestic & male & around 5 & $\begin{array}{l}\text { indoor, previously living } \\
\text { on the street }\end{array}$ & FeLV \\
\hline 10. & Domestic & male & 2 & indoor & FeLV \\
\hline 11. & Persian & female & 14 & back yard & FeLV \\
\hline 12. & Domestic & female & 1 & outdoor access & FeLV \\
\hline 13. & Domestic & male & 3 & outdoor access & FeLV \\
\hline 14. & Domestic & female & 8 & outdoor access & FIV \\
\hline 15. & Domestic & male & 10 & indoor and backyard & FIV \\
\hline 16. & Domestic & male & 8 & indoor & FIV \\
\hline 17. & Domestic & male & 7 & indoor & FIV \\
\hline 18. & Angora & male & 10 & indoor and back yard & FIV \\
\hline 19. & Domestic & female & 1 & $\begin{array}{l}\text { indoor, previously living } \\
\text { on the street }\end{array}$ & FIV \\
\hline 20. & Domestic & male & 4 & $\begin{array}{l}\text { indoor, except in the } \\
\text { summer }\end{array}$ & FeLV \\
\hline 21. & Cross breed & female & 12 & indoor, back yard & FIV \\
\hline
\end{tabular}




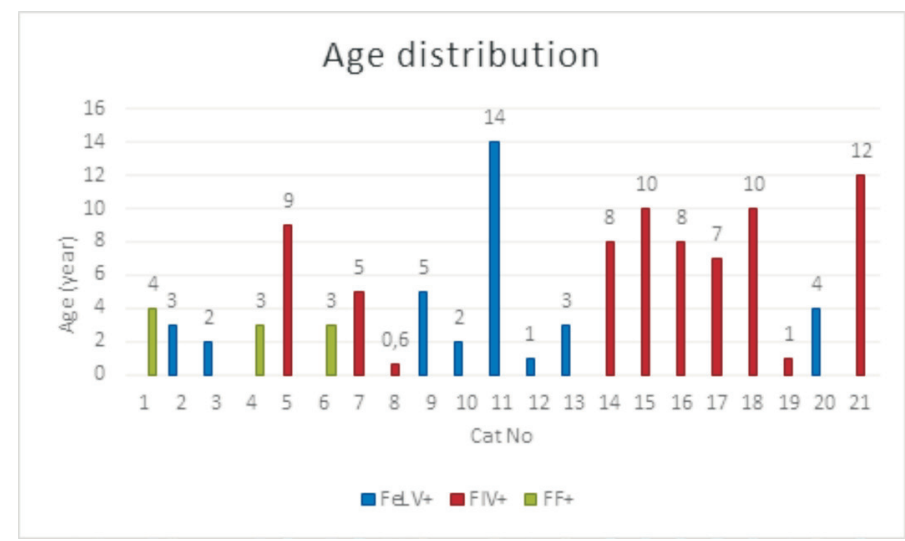

Fig. 1. Age distribution between FeLV+, FIV+ and FF+ cats

The presence of the FeLV antigen was detected in eight cat sera samples, from two females and six males.

The clinical picture of the disease was as follows: male cats: one cat had diarrhoea, rhinitis, sinusitis, and oral lesions; one had stomatitis, gingivitis and pneumonia; two refused food; one had skin changes, bloody diarrhoea and bite caused phlegmon on legs; one had respiratory changes and bite caused leg phlegmon. Female animals: one cat was coughing and had loss of appetite, and the other was very emaciated, with purulent discharge from the nose. The cat had a hairless area on the right mandible.

In terms of age one cat was one year old, two cats were two years, two cats three years, one was four years and one five years old. Only one cat was older, at the age of 14 years.

Concerning the way the cats were kept, six cats had been adopted from an animal shelter, two were kept indoors, but went out sometimes.

One cat had been vaccinated (cat number 10).

The presence of specific antibodies to FIV was detected in ten sera samples, of which four from females and six from males. Six male cats had symptoms of gingivitis and changes in their mouths, long-lasting diarrhoea, one of them had difficulty breathing, and two loss of appetite and weight loss. One female animal was extremely dyspnoeic; one had loss of appetite, was depressed and somnolent; one breathed rapidly and was bleeding from the gums; and one had swollen eyes, enlarged thymus, severe respiratory disorders and an audible groan. 
N. Rudan et al.: Clinical and haematological parameters of feline immunodeficiency and feline leukemia virus infection

With respect to age: one cat was 5 years old, five between 7-10 years, one female cat was 8 years old, one over 12 years, two were between 6 months and one year old.

Concerning the way they were kept: four animals lived in an apartment, house or yard, three in an apartment or house but had previously had outdoor access, and three animals lived permanently indoors.

Out of 21, three serum samples demonstrated the presence of FeLV antigen and FIV antibodies. All three samples originated from male animals.

From the clinical symptoms: one cat had rhinitis, vomiting, was spitting half-chewed food; another had diarrhoea and vomiting, leg wounds, was depressed, had enlarged lymph nodes, gingivitis; and a third was vomiting occasionally and had pale mucous membranes.

All three cats were at the age of 3-4 years.

According to how they were kept: two were kept outdoors, one lived in an apartment and had been vaccinated (patient number 6).

Hematological and biochemical findings.

Erythrocytes. Four of the eight FeLV infected cats had a reduced number of Erc, in comparison with four of the ten FIV infected cats which had decreased values for Erc. From three FF+ cats, one had a slightly reduced number of Erc, and two cats had normal values for Erc.

Leukocytes. Two FeLV+ animals had an increased number of Lkc, while four of the FIV+ cats had an increased number of Lkc, and only one FF+ cat had a slightly lower value of Lkc.

Haemoglobin. Five FeLV + cats had decreased levels of $\mathrm{Hb}$, eight FIV + cats had a decreased level of $\mathrm{Hb}$ and all of the three $\mathrm{FF}+$ cats had normal values for $\mathrm{Hb}$.

HMT. Five FeLV+ cats had decreased levels of HMT in their blood, as well as eight FIV+ cats, while one FF+ cat had slightly a decreased HMT value.

MCV. All FeLV+ cats for which data exist, had decreased levels of MCV, as well as all $\mathrm{FIV}+$ cats with known data, and two of the three FF+ cats also had decreased values.

$\mathrm{MCH}$. Two FeLV+ animals had increased MCH values, also two FIV+, and one FF+ cat had a slightly increased level of $\mathrm{MCH}$.

$\mathrm{MCHC}$. One FeLV+ cat had a slightly decreased value. One FIV+ cat and one FF + also had a slightly decreased value of MCHC.

Lymphocytes. Three of the eight FeLV positive cats had an increased number of lymphocytes in the blood, and three had decreased values. Two of the ten FIV-infected cats had an increased number of lymphocytes, and two animals had decreased values of lymphocites. One of the three FF+ cats had an increased number of lymphocytes. 
Monocytes. Of the four FeLV+ cats in which monocytes were measured, two had normal values, and two had increased values. Of the six FIV+ cats for which data exist, three had decreased values, two had normal values for monocytes, and one had increased levels of monocytes. Two FF+ cats had normal values, and one had a decreased number of monocytes.

Eosinophils. Three FeLV+ cats in which eosinophils were measured had normal values. Four out of five FIV+ cats for which data exist had normal values, while one had an increased value. Two FF+ cats had normal values of eosinophils, and one had an increased value.

Thrombocytes (platelets). Four FeLV+ cats for which data are available had decreased values of thrombocytes, and the three FIV+ cats for which data are available also had decreased values. All three FF+ cats have decreased values of platelets.

Segmented neutrophils. Of the seven FeLV+ animals for which data are available, four had increased values, two decreased, and one had normal values of segmented neutrophils. Out of the nine FIV+ animals for which data exist, four had increased values, two had decreased values, and three had values within the normal range. Two FF+ cats had decreased levels, and one had an increased level of segmented neutrophils.

Non-segmented blood cells (reticulocytes). Five FeLV+ cats for which data are available, had increased values. Four FIV+ cats for which data are available, also had increased values and one $\mathrm{FF}+$ positive cat for which data are available showed an increased value.

ALT. Five FeLV+ animals had increased values for ALT and one had a value within the physiological range. Seven FIV+ cats had normal ALT values, whereas one had a very increased level. All three FF+ cats had ALT within the normal range.

Bilirubin. One FeLV+ cat had an increased value and other cats for which data are available had bilirubin values within the normal range. Two FIV + cats had increased levels of bilirubin, and others for which data exist had bilirubin level within the normal range. One FF+ cat had an increased bilirubin value.

Glucose. Three out of four FeLV+ animals for which data exist had a low level of glucose in their blood, and one had a normal level. Five out of six FIV+ animals for which data exist had normal levels, one had an increased value of glucose in the blood. Two $\mathrm{FF}+$ cats had normal values, and one had a slightly increased blood glucose value.

Total protein and albumin. All FeLV+ animals had normal values of total protein and albumin. Four FIV+ cats had increased values of total protein, three FIV+ had slightly decreased values of albumin, another two had normal values for albumin, and for one patient there are no data. All three $\mathrm{FF}+$ positive cats had values of total protein within the normal range, and one had a decreased value for albumin. 
Urea. Two FeLV+ animals had increased values for urea, and for others for which data exist the values are within the normal range. One FIV+ animal had an increased value for urea, and the others for which data exist had values within the normal range.Two out of three $\mathrm{FF}+$ positive cats had increased values for urea.

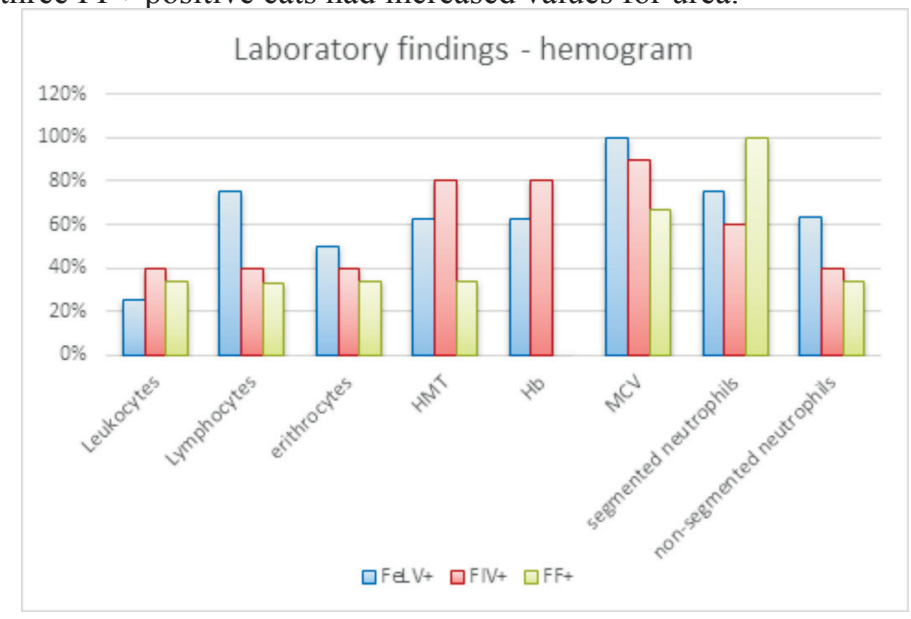

Fig. 2. FeLV+, FIV+ or FF+ cats with altered blood cell values, either increased ordecreased

Table 2. The number and percentage of cats with some blood cell hematological alterations including both increased and decreased values, as indicated by arrows ( $\uparrow$-increased, $\downarrow$-decreased)

\begin{tabular}{|l|c|c|c|}
\hline Blood cells & FeLV+ & FIV+ & FF+ \\
\hline Leukocytes & $\uparrow 2(25 \%)$ & $\uparrow 4(40 \%)$ & $\downarrow 1(33.3 \%)$ \\
\hline Lymphocytes & $\uparrow 3(37.5 \%)$ & $\uparrow 2(20 \%)$ & $\uparrow 1(33.3 \%)$ \\
\hline Erythrocytes & $\downarrow 3(37.5 \%)$ & $\downarrow 2(20 \%)$ & $\downarrow 4(50 \%)$ \\
\hline HMT & $\downarrow 5(62.5 \%)$ & $\downarrow 4(40 \%)$ & $\downarrow 1(33.3 \%)$ \\
\hline MCV & $\downarrow 8(100 \%)$ & $\downarrow 9(80 \%)$ & $\downarrow 1(33.3 \%)$ \\
\hline Segmented neutrophils & $\uparrow 4(50 \%)$ & $\uparrow 4(40 \%)$ & $\uparrow 1(33.33 \%)$ \\
\hline Non-segmented neutrophils & $\uparrow 5(62.50 \%)$ & $\uparrow 4(40 \%)$ & $\uparrow 1(33.33 \%)$ \\
\hline
\end{tabular}

\section{Discussion}

Immunodeficiency and leukaemia virus in cats are globally spread viruses. The results reported in this study generally correspond to the results of other similar studies, 
although some conclusions could not be drawn on the basis of the data collected and the number of animals studied.

Collado et al. in their research from 2012 performed on $78 \mathrm{FIV}+$ and / or FeLV + cats, found that FIV + cats are significantly younger than FeLV + cats, and generally have more severe symptoms of the disease than FIV + cats (COLLADO et al., 2012). In our research as well FIV + cats were generally younger than FeLV + cats.

Doubly infected cats showed less severe symptoms than mono-infected animals, and the results were in general closer to those of FIV+ than FeLV+ cats (COLLADO et al., 2012), which was also observed in our study.

In research from 2008 that included 967 cats, risk factors for FIV and FeLV sera positivity were studied, including age, sex, sexual intactness of female cats or castrated males, the way the animals are kept, former results of serological tests, vaccination, and history of bite wounds and their location (head and neck, front limbs, trunk, back limbs, tail or lumbar area). It was concluded that the age (adult), sex (male), history of skin wounds and the way they are kept (outdoor access) are significantly connected with seropositivity. Twice as many male cats were treated for skin wounds as female cats. From 967 cats that were subject to serological testing, $85(8.8 \%)$ were seropositive for FeLV antigens and $123(12.7 \%)$ were positive for FIV antibodies. Twenty-one cats $(2.17 \%)$ were positive for FeLV antigens and FIV antibodies (DUNHAM and GRAHAM, 2008).

In our study, four cats $(19.05 \%)$ had bite wounds at the time of treatment, all of which were males. Three animals with bite wounds were FeLV + and one FeLV+ and FIV+. Concerning the age of the cats that were admitted for treatment, the cats were between 6 months and 14 years of age. Of the $8 \mathrm{FeLV}+$ cats, six of them were at an age from 2 to 5 years $(75 \%)$, and of the FIV+ animals most were at an age between 7 and 10 years $(60 \%)$. All three FeLV+ and FIV+ animals were between 3 and 4 years of age. Three animals from the 21 tested were at the age of one year or less, and two were between 12 and 14 years old.

FeLV is primarily transmitted in saliva and respiratory tract secretions, but also in urine, faeces, tears and milk (HOFMANN-LEHMANN et al., 2001). Infection is also transmitted by sharing food and water bowls, and keeping animals together. FeLV enters into a cat's body by oronasal inoculation and travels to the oropharyngeal lymphatic tissue, where it replicates. At this stage an effective or non-effective immune response may occur. If the immune response is not effective, the virus spreads to the spleen, lymph nodes, intestines and bladder epithelial cells, salivary glands and bone marrow, infecting mononuclear cells in the peripheral blood (ADDIE et al., 2000). The outcome of FeLV infection in domestic cats varies (permanent, temporary or asymptomatic), in relation to amount of provirus, where permanently infected cats have a higher amount of provirus and weak humoral immune response (HOFMANN-LEHMANN et al., 2001). 
FIV is also generally spread in saliva and it is transmitted mostly via bite wounds (YAMAMOTO et al., 1989; PEDERSEN, 1993; ISHIDA et al., 1989). In Madrid ARJONA et al. (2007) undertook sero-epidemiological research into FeLV and FIV infection in relation to some clinical aspects. They compared the presence of infection in 180 healthy animals and 115 animals that showed symptoms such as anorexia, depression, fever, lymphomegaly, stomatitis, rhinotracheitis, generalized skin infections or tumours. It was concluded that the clinical symptoms are very unspecific, and a high percentage of animals with clinical signs typical for FIV or FeLV were negative for both retroviruses.

Of our tested cats, four FeLV positive cats had symptoms of pneumonia $(50 \%)$, two animals had diarrhoea (25\%), three had sinusitis $(37.5 \%)$, two had gingivitis and stomatitis (25\%), and eight anorexia and weight loss (100\%). Two FeLV and one FF positive cats had generally enlarged lymph nodes.

This corresponds to the fact that the most common clinical manifestations in FeLV infected cats are secondary infections as a result of severe immunodeficiency (LIEM et al., 2013).

Malignant lymphoma, often connected with FeLV, was not recorded in the cats included in our research; only one cat had a adenocarcinoma.

It is thought that $30 \%$ of infected animals develop anaemia with the retrovirus infection. Myelodysplastic syndrome, characterised by anaemia, leukopenia and thrombocytopenia, is often a sign of infection with an FeLV C-subtype (HARDY and ESSEX, 1986).

In cats researched in Spain, the number of erythrocytes and leukocytes was decreased in $50 \% \mathrm{FeLV}+$ cats, $44 \%$ of FIV positive cats, but only $14 \% \mathrm{FF}+$ cats had anaemia. In cats infected with FIV there were no dominant clinical changes. The reason may be that the studied cats were in different clinical phases of the disease, and each was characterised by specific symptoms. The most common changes were neutropenia and lymphopenia (33.3 FeLV+ cats) and lymphopenia (37.5\% FIV+ cats), (COLLADO et al., 2012).

Our results also indicate that FeLV and FIV infections are connected with anaemia.

Erythropoiesis is supressed because viruses kill growing cells and precursors of myeloid and erythroid cells. 46.2\% FeLV+ cats had leukopenia, 30.8\% leucocytosis. There was a statistically significant connection between leukopenia and FeLV infection $(\mathrm{P}<0.05)$, that corresponds to the fact that the most common clinical manifestation in FeLV infected cats is the development of a secondary infection due to significant immunodeficiency (HARDY and ESSEX, 1986).

In our research, $50 \%$ of FeLV+ and $40 \%$ of FIV+ cats had erythropenia, and $62.5 \%$ FeLV+ and $80 \%$ FIV+ had decreased HMT, 100\% of animals had decreased MCV. 25\% FeLV + and $40 \%$ FIV + cats had leukocytosis. A one-year-old FIV+ cat had engrossed thymus and lymph nodes, two cats had an unevenly shaped formation in the epigastrium. 
N. Rudan et al.: Clinical and haematological parameters of feline immunodeficiency and feline leukemia virus infection

Some researchers showed that infection with feline retroviruses can induce kidney lesions due to clusters of immune complexes in the kidney tissue (DUNHAM and GRAHAM, 2008; ADDIE et al., 2000).

In this research, out of eight FeLV infected cats, four had one enlarged kidney and kidneys painful to touch (50\%), and two had glomerulonephritis (25\%). Out of ten FIV+ cats, three showed painful kidneys on palpitation (30\%) and one had hydro-nephrosis on both kidneys (10\%).

Research in Spain pointed out that the number of cats with increased values for creatinine ( $>1$ to $2 \mathrm{mg}$ of creatinine /dl) in three groups of animals was 9.1; 16.7 and $13.2 \%$ respectively. In that research no significant difference was noticed in values of urea and creatinine, that would indicate kidney failure, between non-infected and infected cats. High levels of urea (>20 to $50 \mathrm{mg}$ urea/dl) were noticed in $45.8 \%$ of FeLV + cats, $62.5 \%$ of FIV + cats and $51 \%$ of FIV and FeLV negative cats (COLLADO et al., 2012).

High levels of creatinine ( $>1$ to $2 \mathrm{mg}$ of creatinine /dl) were recorded in $3 \mathrm{FeLV}+$ cats $(37.5 \%), 5 \mathrm{FIV}+$ cats $(50 \%)$ and one $\mathrm{FF}+$ cat $(33.3 \%)$ in our study. According to our research two FeLV + cats, one FIV+ and two FF+ cats had increased values for urea. High levels of creatinine were recorded in three FeLV+ cats (37.5\%), $5 \mathrm{FIV}+$ cats $(50 \%)$, and one FF cat $(33.3 \%)$.

According to research in the USA, most infected cats were aged above three years (LEVY et al., 2006).

According to our research, the disease was more common in adult cats, where 13 cats were over three years old.

\section{References}

ADDIE, D. D., J. M. DENNIS, S. TOTH, J. J. CALLANAN, S. REID, O. JARRETT (2000): Longterm impact on a closed household of pet cats of natural infection with feline coronavirus, feline leukaemia virus and feline immunodeficiency virus. Vet. Rec. 146, 419-424.

ARJONA, A., N. BARQUERO, A. DOMÉNECH, G. TEJERIZO, V. M. COLLADO, C. TOURAL, D. MARTIN, E. GOMEZ-LUCIA (2007): Evaluation of a novel nested PCR for the routine diagnosis of feline leukemia virus (FeLV) and feline immunodeficiency virus (FIV). J Feline Med. Surg. 9, 14-22.

BENDINELLI, M., M. PISTELLO, S. LOMBARDI, A. POLI, C. GARZELLI, D. MATTEUCCI, L. CECCHERINI-NELLI, G. MALVADI, F. TOZZINI (1995): Feline immunodeficiency virus: an interesting model for AIDS studies and an important cat pathogen. Clin. Microbiol. Rev. 8, 87-112.

BOENZLI, E., M. HADORN, S. HARTNACK, J. HUDER, R. HOFMANN-LEHMANN, H. LUTZ (2014): Detection of antibodies to the feline leukemia virus (FeLV) transmembrane 
N. Rudan et al.: Clinical and haematological parameters of feline immunodeficiency and feline leukemia virus infection

protein p15E: an alternative approach for serological FeLV detectionbased on antibodies to p15E. J. Clin. Microbiol. 52, 2046-2052.

COLLADO, V. M., A. DOMENECH, G. MIRÓ, S. MARTIN, E. ESCOLAR, E. GOMEZ-LUCIA (2012): Epidemiological aspects and clinicopathological findings in cats naturally infected with feline leukemia virus (FeLV) and/or feline immunodeficiency virus (FIV). OJVM 2, 13 20.

COURCHAMP, F., D. PONTIER (1994): Feline immunodeficiency virus: an epidemiological review. C. R. Acad. Sci. Ser. III 317, 1123-1134.

DUNHAM, S. P., E. GRAHAM (2008): Retroviral infections of small animals. Vet. Clin. North. Am. Small Anim. Pract. 38, 879-901.

ENGLiSH, R. V., P. NELSON, C. M. JOHNSON, M. NASISSE, M. B. TOMPKINS (1994): Development of clinical disease in cats experimentally infected with feline immunodeficiency virus. J. Infect. Dis. 170, 543-552.

FONTENOT, J. D., E. A. HOOVER, J. H. ELDER, R. C. MONTELARO (1992): Evaluation of feline immunodeficiency virus and feline leukemia virus transmembrane peptides for serological diagnosis. J. Clinic. Microbiol. 30, 1885-1890.

GLEICH, S. E., S. KRIEGER, K. HARTMANN (2009): Prevalence of feline immunodeficiency virus and feline leukaemia virus among client-owned cats and risk factors for infection in Germany. J. Feline Med. Surg. 11, 985-992.

GOLDKAMP, C. E., J. K. LEVY, C. H. EDINBORO, J. L. LACHTARA (2008): Seroprevalences of feline leukemia virus and feline immunodeficiency virus in cats with abscesses of bite wounds and rate of veterinarian compliance with current guidelines for retrovirus testing. J. Am. Vet. Med. Assoc. 232, 1152-1158.

HARDY, W. D. Jr, M. ESSEX (1986): FeLV-induced feline acquired immune deficiency syndrome. A model for human AIDS. Prog. Allergy 37, 353-376.

HOFMANN-LEHMANN, R., J. B. HUDER, S. GRUBER, F. BORETTI, B. SIGRIST, H. LUTZ (2001): Feline leukaemia provirus load during the course of experimental infection and in naturally infected cats. J. Gen. Virol. 82, 1589-1596.

ISHIDA, T., T. WASHIZU, K. TORIYABE S. MOTOYOSHI, I. TOMODA, N. C. PEDERSEN (1989): Feline immunodeficiency virus infection in cats of Japan. J. Am. Vet. Med. Assoc. 194, 221-225.

LEVY, J. K., H. M. SCOTT, J. L. LACHTARA, P. C. CRAWFORD (2006): Seroprevalence of feline leukemia virus and feline immunodeficiency virus infection among cats in North America and risk factors for seropositivity. J. Am. Vet. Med. Assoc. 228, 371-376.

LIEM, B. P., N. K. DHAND, A. E PEPPER, V. R. BARRS, J. A. BEATTY (2013): Clinical findings and survival in cats naturally infected with feline immunodeficiency virus. J. Vet. Intern. Med. 27, 798-805.

MELI, M. L., V. CATTORI, F. MARTíNEZ, G. LÓPEZ, A. VARGAS, F. PALOMARES, J. V. LÓPEZ-BAO, R. HOFMANN-LEHMANN, H. LUTZ (2010): Feline leukemia virus 
N. Rudan et al.: Clinical and haematological parameters of feline immunodeficiency and feline leukemia virus infection

infection: a threat for the survival of the critically endangered Iberian lynx (Lynx pardinus). Vet. Immunol. Immunopathol. 134, 61-67.

PEDERSEN, N. C. (1993): The feline immunodeficiency virus. In: The Retroviridae, Vol. 2 (Levy, J. A., Ed.), Plenum, New York, p.p. 181-228,

SCHLECHT-LOUF, G., M. MANGENEY, H. EL-GARCH, V. LACOMBE, H. POULET, T. HEIDMANN (2014): A targeted mutation within the feline leukemia virus (FeLV) envelope protein immunosuppressive domain to improve a canarypox virus-vectored FeLV vaccine. J. Virol. 88, 992-1001.

YAMAMOTO, J. K., H. HANSEN, E. W. HO, T. Y. MORISHITA, T. OKUDA, T. R. SAWA, R. M. NAKAMURA, N. C. PEDERSEN (1989): Epidemiologic and clinical aspects of feline immunodeficiency virus infection in cats from the continental United States and Canada and possible mode of transmission. J. Am. Vet. Med. Assoc. 194, 213-220.

Received: 25 May 2016

Accepted: 21 June 2017

\section{RUDAN, N., E. MARKOVIĆ, N. KUČER: Procjena kliničkih i hematoloških pokazatelja u razlikovanju infekcije virusom mačje imunodeficijencije i virusom leukemije mačaka. Vet. arhiv 87, 731-743, 2017. SAŽETAK}

U radu su istraženi klinički, hematološki i virološki pokazatelji ustanovljeni kod 21 mačke zaprimljene na Klinici za unutarnje bolesti na Veterinarskom fakultetu Sveučilišta u Zagrebu, s izraženim kliničkim znakovima leukemije mačaka, mačje imunodeficijencije ili obiju bolesti zajedno. Mačke su se razlikovale po podrijetlu, dobi i načinu držanja. Za svaku mačku bilježena je klinička slika bolesti, vrijednosti temperature te frekvencija bila i disanja. Specifična protutijela za virus imunodeficijencije (engl. feline immunodeciciency virus, FIV) ustanovljena su u uzorcima seruma 10 životinja, od kojih su četiri bile ženskog, a šest muškog spola. FeLV (engl. feline leukemia virus) antigen ustanovljen je u osam uzoraka seruma, od kojih su dva bila podrijetlom od ženskog, a šest od životinja muškog spola. Tri uzorka bila su FIV i FeLV pozitivna, a pripadala su životinjama muškog spola. Životinje muškog spola i one koje su boravile na otvorenom, bile su znatno prijemljivije za infekciju. FeLV+ i FF+ mačke bile su uglavnom mlađe od FIV+ (sedam od osam FeLV pozitivnih mačaka bilo je u dobi od 1 do 5 godina starosti). Zabilježene su razlike između FeLV i FIV pozitivnih životinja s obzirom na hematološke i biokemijske pokazatelje. Uglavnom su ustanovljene povišene vrijednosti leukocita, segmentiranih i nesegmentiranih neutrofila u mačaka pozitivnih na FeLV, FIV ili na oba virusa, jednako kao i smanjene vrijednosti trombocita, eritrocita, HMT i MCV u pretraženih životinja. U FeLV pozitivnih životinja uočljivije su bile promjene u broju limfocita (limfocitoza i limfopenija) u odnosu na FIV pozitivne životinje u kojih je bila prisutnija leukocitoza. Povezanost između izraženosti kliničkih simptoma te dobi i spola životinja nije ustanovljena.

Ključne riječi: FIV, FeLV, mačke, prirodna infekcija, klinički znakovi, hematološki pokazatelji 
